\title{
Willingness to pay for ecolabelled products: the case of traditional rice varieties in the Philippines
}

\author{
Carol Balgos $^{1 *}$, Larry Digal ${ }^{2}$ \\ ${ }^{1}$ Research Associate, University of the Philippines Mindanao, Davao City \\ ${ }^{2}$ Professor, School of Management, University of the Philippines Mindanao, Davao City, Philippines
}

How to cite this paper: Balgos, C., Digal, L.. (2019) Willingness to pay for ecolabelled products: the case of traditional rice varieties in the Philippines. International Journal of Food Science and Agriculture, 3(3), 205-219.

DOI: $10.26855 /$ ijfsa.2019.09.010

*Corresponding author: Carol Balgos, Research Associate, University of the Philippines Mindanao, Davao City.

Email: cqbalgos@up.edu.ph

\begin{abstract}
Philippines is one of the megadiverse countries in the world and home to globally important agricultural biodiversity particularly in rice. However, the diversity is eroded as some traditional rice varities are no longer produced. Some farmers, however, do not continue to plant traditional varieties of rice because they are not profitable. While there is an opportunity to continue producing them as consumers begin to recognize the importance of preserving traditional varieties, it is uncertain whether this opportunity translates to better incentives for farmers. A survey of 230 consumers in Luzon, Visayas and Mindanao was done to examine this opportunity particularly the demand and willingness to pay for ecolabelled products from these traditional varieties. Factors that affect the level of price premium were also analyzed using interval regression analysis. Results show that most consumers are willing to pay for a premium although they vary depending on the level of price premium. Certification fetches higher price and majority of the respondents are willing to pay price premium for ecolabelled products that range from $10 \%$ to $20 \%$. Results show that gender, age, income and being an organic product consumer significantly affect the level of price premium particularly the demand and willingness to pay for ecolabelled products from these traditional varieties. Factors that affect the level of price premium were also analyzed using interval regression analysis. Results show that most consumers are willing to pay for a premium although they vary depending on the level of price premium. Certification fetches higher and majority of the respondents are willing to pay price premium for ecolabelled products that from $10 \%$ to $20 \%$. Results show that gender, age, income and being an organic product consumer significantly affect the level of price premium.
\end{abstract}

\section{Keywords}

ecolabelled products; Philippines; price premium

\section{Introduction}

Philippines is one of the megadiverse countries in the world and considered to be a biodiversity hotspot. It is home to diverse species of plants, animals and microorganisms where more than half are found only in the Philippines. It is also home to globally important agricultural biodiversity such as in rice and rootcrops.

One way to preserve biodiversity in agriculture or agro-biodiversity is to provide opportunity for the farming community to derive sufficient economic benefits from conserving these traditional varieties such as rice. However, a key constraint to this opportunity is the dearth of information and awareness of consumers about the social, economic, nutritional and ecological value of traditional varieties. Previous studies show a potential for organic products such as traditional varieties of rice with annual industry growth rates of $10-20 \%$ and a price premium that ranges from $20-30 \%$ (Concepcion, et al 2008) [1]. 
There are a number of products that are branded or labeled as environment friendly to respond to opportunities created by the awareness and value consumers place in preserving the environment. These products are generally known as ecolabelled products.

This paper attempts to examine the market potential for ecolabelled products particularly the traditional rice varieties in the Philippines. The paper is organized as follows. Section 2.0 presents some previous studies followed by section 3.0 which covers the discussion on the methodology used in the analysis. Section 4.0 provides an overview of the market for traditional rice in the Philippines while section 5.0 contains the analysis of market potential of traditional or indigenous varieties. Finally, summary and conclusions are discussed in Section 6.0.

\section{Previous studies}

There a number of studies that have explored the willingness to pay for environmental products and attributes (eg Aoki, et al, 2016; Lozano et al 2010; Rex and Baumann 2006). Of these, some focused on organic products such as Sriwaranun, et al (2015) in Thailand, Sirieix, et al (2011) in China and Kuo et al (2005) in Taiwan. There were also studies specific to rice that include Kajale and Baker (2015) in India, Flamohe et al (2015) in Togo and Ara (2003) in the Philippines. The latter analyzed the multiple attributes of organic rice in Manila and Naga City while this study covered more areas and types of rice including brands and labels.

A useful framework that illustrates the value of market-based mechanism such as ecolabelling is the one by Treves and Jones (2009). According to this framework, a trade-off exists between increasing consumer confidence through verification and the willingness of producers to participate because of the costs of verification. Consumer confidence increases while producer incentive decreases as the effort of verification increases as shown in the framework they developed in Figure 1 as applied to wildlife conservation.

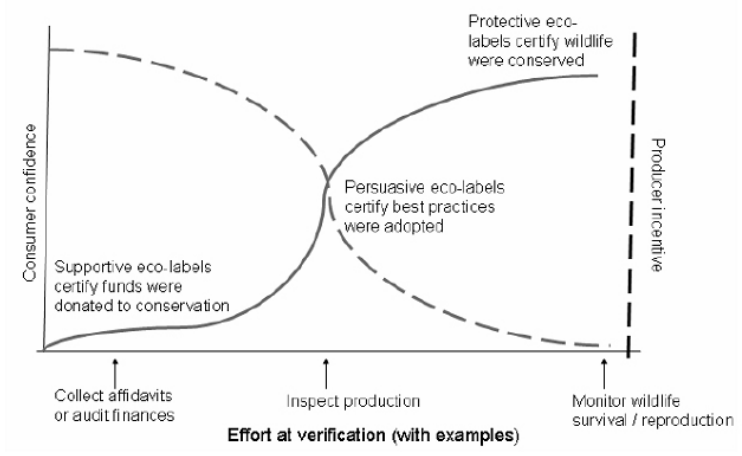

Source: Treves and Jones (2009)

Figure 1.

In this framework, they also came up with three classifications of ecolabels based on the effort of verification namely, supportive, persuasive and protective ecolabels. Supportive ecolabels have lower degree of verification. Persuasive ecolabels are those that certify the methods of production but not conservation itself as done in protective ecolabels. They classified ecolabels based on these three categories.

They further argued that there is a tradeoff between increasing confidence of consumers through higher effort of verification and providing incentives to producers. This is due to the fact that increasing effort of verification increases cost which lowers incentives for producers and may put pressure to certifiers to relax the standards. Moreover, they also raised the issue that profits may not be a realistic goal for ecolabels that have higher effort of verification such as persuasive and protective ecolabels. As such, while market-based mechanism can help protect the environment, the state in most cases is in a better position to provide this public good [2].

A study by Amstel, et al., (2007) was done to examine to what extent ecolabels in the Netherlands contain standards that promote conservation and sustainable use of agro-biodiversity particularly on-farm biodiversity of agricultural landscapes. They found that the ecolabels contain some standards that promote agro-biodiversity but the differences 
across labels varied extensively. They concluded that the five ecolabels they examined were insufficient for the Dutch government to use as part of a governance strategy to promote agro-biodiversity.

There were a number of issues that were identified in using ecolabels. A study by (Amstel, et. Al., (2008) assessed the reliability of information of five food ecolabels particularly on the aspects of biodiversity, reference to rule of law to assure buyer's confidence, farmer's compliance and ecological impact. They found that there was ambiguity on environmental themes. The information about the compliance of producers was also inadequate and there was failure to assure the buyers of the ecological impact of the products that are ecolabelled.

Market and government policy also play an important role in promoting agro-biodiversity conservation. In the case of natural rubber latex in Indonesia (Akiefnawati et al., 2011), farmers have difficulty complying with the certification standards of the Forestry Stewardship Council (FSC). There were no factories that were willing to receive ecocertified rubber as the market for certified-rubber is underdeveloped. There was also conflict with government's policy particularly in supporting palm-oil production while no policy supports rubber agro-forestry conservation.

There are three challenges in marketing ecolabelled products according to Ottman, et al., (2006). These are the so called three Cs, namely: consumer value, credibility of claims and calibration of marketing messages to minimize confusion. While ecolabelled products minimize competition as they cater to different market segments, they should be able to create value for consumers based on quality or convenience. They must also pass scrutiny from various groups and be able to communicate clearly the value of the product.

Combining ecolabels and geographic indication (GI) can strengthen small rural producer's development, conservation of biodiversity and marketing efforts (Guerra 2004). This is because GI is a collective guarantee with regards the biological identity and quality of the product particularly in developing countries where biological resources are not usually marketed through brands. Thus, GIs can strengthen market access and can be used as a tool to regulate harvesting and promote rational land use strategies and in-situ conservation of biodiversity (Guerra 2004).

Incentives for producers of ecolabelled products have become attractive which explain why "green advertising" has increased in the last few years but many consumers who patronize green products want certification to be verified. In Indonesia for example, rain forest certified Robusta and Arabica coffee are priced $47 \%$ and $13 \%$ higher compared to non-certified Robusta and Arabica coffee (EEPSEA Policy Brief 2013).

\section{Methodology}

There were three types of ecolabelled rice products that were analyzed to examine their demand and willingness to pay. These were certified organic rice, rice products labeled or sold as organic but without organic certification from a third party or an organization that issues organic certification and lastly rice products certified to preserve Ifugao rice terraces as cultural heritage. Ifugao is a province in the Philippines known for its remarkable rice terraces. In the Philippines, it is known to be eighth wonder of the world. In 2013, two municipalities in the province, namely Hingyon and Hungduan are declared as a National Important Agricultural Heritage Site. This trademark is part of the initiative of the Food and Agriculture Organization's program on Globally Important Agricultural Heritage Sites.

A survey was conducted which generated a sample of 230 consumers. A model was estimated to examine the factors that affect the level of price premia that consumers are willing to pay for products covered. In order to ensure that the respondents understand the reasons why the products are ecolabelled, it was explained in the introductory paragraph of the survey that the purpose was to understand the factors that determine demand for environment friendly products or eco-labelled products. It was also mentioned that the results of the survey will be used to develop eco-labelled products and inform government and private sectors to support the promotion of these products that help preserve our environment. Also, the respondent was asked if he is willing to pay for a price premium for ecolabelled products before he or she proceeds to choose the range of price premia. Thus, the respondent attaches a value contingent on the information about the attribute of the product that promotes preservation of the environment.

Interval regression was used to examine the factors that affect the level of price premia that consumers are willing to pay for the ecolabelled products covered. This method is appropriate since we know from the survey the range of premia that the consumers are willing to pay but not the exact premium. The Gnu Regression, Econometrics Library (GRETL) software was used to estimate the model. 
The model for price premia is specified as follows:

$\mathrm{PP}=\mathrm{f}(\mathrm{I}, \mathrm{H}, \mathrm{C}, \mathrm{G})$

Where

$\mathrm{PP}=$ price premium specified in nine categories or ranges of price premia

$\mathrm{I}=$ income specified in four income levels or brackets

below USD 326/month

USD 327/mo. - USD 652/mo.

USD 653 - USD 1,087

USD 1,088 - USD 1,522

$\mathrm{H}=$ level of health consciousness: 1 if consider self as health conscious and 0 otherwise

$\mathrm{C}=$ consumption of organic products: 1 if consuming organic labeled products and 0 otherwise

$\mathrm{G}=$ gender: 1 if male and 0 if female

Imposing a linear functional form, the model estimated was:

\section{Traditional varieties of rice in the Philippines}

The market is expanding for traditional varieties of rice in the Philippines which are usually grown without the use of chemicals. This is in response to changing market conditions where consumers increasingly appreciate living a healthy lifestyle. Part of this is the increasing consumption of organic products. According to Philexport, demand for organic products increased by $20-30 \%$ per year (www.philexport.ph).

The value chain for traditional varieties of rice is similar to commercial (modern variety) of rice. For commercial rice, palay or unmilled rice is sourced from the farmers, then sold to traders in the barangay and some are consolidated by municipal traders who mill the rice themselves or sell to large millers. They are then sold to wholesalers and retail outlets that include small retailers in wet markets, supermarkets and institutional buyers such as hotels, restaurants and fast food. Inputs such as fertilizers and seeds are sourced from various outlets including traders who also finance rice production. In some cases, farmers are able to get credit from government financial institutions, micro-finance institutions and non-government organizations. Technical and extension services are provided by government, nongovernment organizations and private sector.

The main difference between the value chain for traditional rice varieties and commercial rice is the market outlets. Traditional varieties are sold mostly in supermarkets, specialty stores and sometimes they are sold directly by farmers to tourists, hotels and restaurants and consumers (Figure 2). They are also sold in traditional wet markets but more recently, they are sold mostly in modern retail outlets such as supermarkets, hypermarkets and specialty stores.

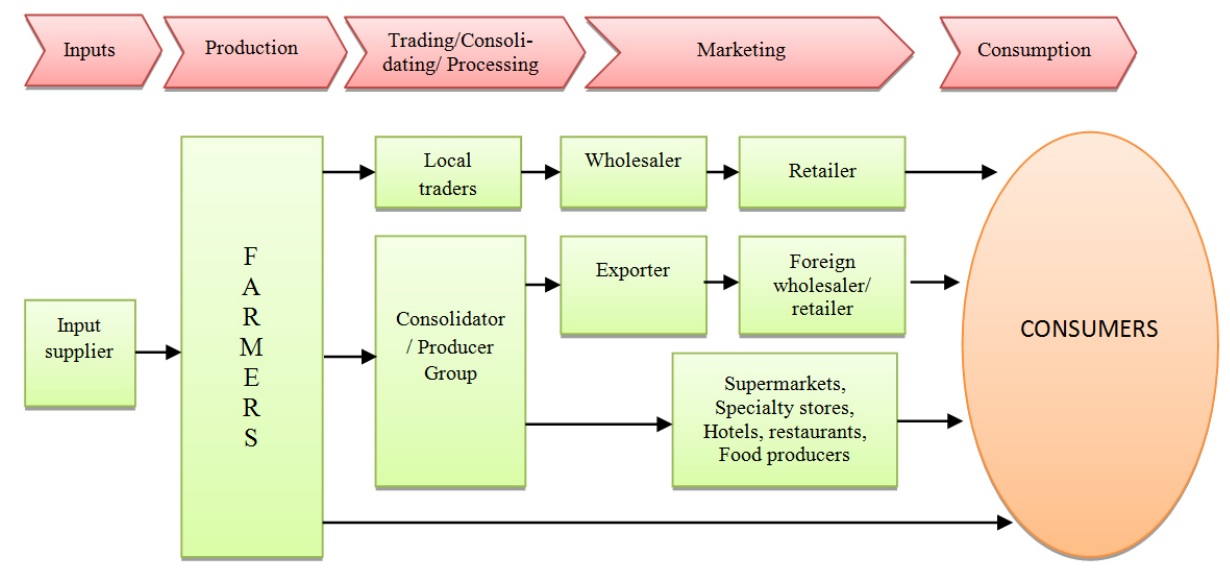

Figure 2. Value Chain for Traditional Rice Varieties 
The market for the traditional varieties of rice is quite competitive given the number of brands available in the market produced by small famers and large companies from Luzon, Visayas and Mindanao. There are 16 brands based on the market outlets scanned for traditional varieties such as supermarkets, specialty stores, trade fairs, retail stores, and organic weekend markets (Table 1). Scanning was done within two month period (October to November 2014) although majority of the data were collected within a three day period in November. This is to factor out the time element that may affect prices for more accurate comparison of brands across market outlets. The type of market outlets was also included as they also affect prices. Differences in retail or marketing costs across types of market outlets also affect retail prices. It is true that organic products are not necessarily expensive but sometimes they are cheaper because of other factors. These include supply factors (volume of production), seasonality and retailing or marketing costs. If prices are compared to non-organic products, quality of the product should also be considered aside from the aforementioned factors. Generally, however, organic products are more expensive because of low volume of production and productivity. Marketing cost per unit is also high due to low volume of production particularly for small farmers. They are also sold in specialty markets catering to relatively affluent consumers (Table 1).

There are three types of labels that can be gleaned from this list of products of traditional rice varieties. These are: 1) labeled as organic that is certified 2) labeled as organic but without certification 3) without organic labels. In what follows, the effect of factors such as certification, location, and type of product (color) on price are discussed.

\subsection{Certification}

Rice products with organic certification such as Fresh Start, Gilded Grains, and Bios Dynamis are priced higher than those without certification. Prices range from USD 1.2 - USD 3.9/kg. (@ 1 USD to 46 Philippine pesos) and packed in $1 \mathrm{~kg}$ to $2 \mathrm{kgs}$. On the average, certified organic rice is priced at USD 3.9/kg. (Table 2). These products can be found in specialty stores such as the echo stores in Bonifacio Global City \& Makati, Department of Agriculture's Agribusiness Center, and in Bios Dynamis outlets in Manila and Davao City. Third party organic certification used in these products came from the Organic Certification Center of the Philippines (OCCP) and Negros Island Organic Certification Services (NICERT).

Table 1. Price of traditional rice by brand, label, market outlet, and weight

\begin{tabular}{|c|c|c|c|c|c|c|c|c|}
\hline \multirow{2}{*}{ Variety/Brand } & \multirow{2}{*}{ Label } & \multirow{2}{*}{$\frac{\text { Type of product }}{\text { (as part of label) }}$} & \multirow{2}{*}{$\begin{array}{l}\text { Packed/ } \\
\text { Produced by }\end{array}$} & \multirow{2}{*}{$\begin{array}{l}\text { Main office } \\
\text { address }\end{array}$} & \multirow{2}{*}{$\frac{\text { Market outlet }}{\text { sold }}$} & \multirow{2}{*}{ Weight } & \multirow{2}{*}{$\begin{array}{l}\text { Price } \\
\text { (PhP) }\end{array}$} & \multirow{2}{*}{$\begin{array}{c}\text { Price/kg } \\
\text { (Php) }\end{array}$} \\
\hline & & & & & & & & \\
\hline Fresh Start & $\begin{array}{l}\text { NICERT } \\
\text { certified } \\
\text { organic }\end{array}$ & $\begin{array}{l}\text { Heirloom variety } \\
\text { Red rice }\end{array}$ & $\begin{array}{l}\text { Fresh Start } \\
\text { Organics }\end{array}$ & $\begin{array}{l}\text { No. 3-A, SJ } \\
\text { Building, } \\
\text { Sta. Clara Drive, } \\
\text { Brgy. Mandalagan, } \\
\text { Bacolod City }\end{array}$ & $\begin{array}{l}\text { Echo store } \\
\text { Makati }\end{array}$ & $2 \mathrm{~kg}$ & 5.9 & 2.9 \\
\hline Bios dynamis & $\begin{array}{l}\text { OCCP } \\
\text { certified }\end{array}$ & $\begin{array}{l}\text { Black rice, red, } \\
\text { brown }\end{array}$ & Bios dynamis & $\begin{array}{l}\text { Magsaysay Ave., } \\
\text { Mlang, Cotabato }\end{array}$ & $\begin{array}{l}\text { Echo store } \\
\text { Makati }\end{array}$ & $1 \mathrm{~kg}$ & 3.9 & 3.9 \\
\hline Gilded Grains & $\begin{array}{l}\text { NICERT } \\
\text { certified } \\
\text { organic }\end{array}$ & $\begin{array}{l}\text { Export quality } \\
\text { Organic-RED } \\
\text { gold }\end{array}$ & $\begin{array}{l}\text { Better country } \\
\text { community } \\
\text { corporation }\end{array}$ & $\begin{array}{l}\text { Better Country, } \\
\text { Don Simeon cor } \\
\text { Silangan, San } \\
\text { Lorenzo, Gapan } \\
\text { City NE } 3105\end{array}$ & $\begin{array}{l}\text { DA } \\
\text { Agribusiness } \\
\text { Center }\end{array}$ & $1 \mathrm{~kg}$ & 3.5 & 3.5 \\
\hline Bios dynamis & $\begin{array}{l}\text { OCCP } \\
\text { certified }\end{array}$ & $\begin{array}{l}\text { Black rice, red, } \\
\text { brown }\end{array}$ & Bios dynamis & $\begin{array}{l}\text { Magsaysay Ave., } \\
\text { Mlang, Cotabato }\end{array}$ & $\begin{array}{l}\text { Davao Bios } \\
\text { dynamis } \\
\text { outlet }\end{array}$ & $1 \mathrm{~kg}$ & 1.2 & 1.2 \\
\hline $\begin{array}{l}\text { Tawid Hill } \\
\text { Exotic Rice }\end{array}$ & Organic* & Brown rice & & & $\begin{array}{l}\text { Echo store } \\
\text { Makati }\end{array}$ & $1 \mathrm{~kg}$ & 3.5 & 3.5 \\
\hline
\end{tabular}


Table 1. cont.

\begin{tabular}{|c|c|c|c|c|c|c|c|c|}
\hline \multirow{2}{*}{ Variety/Brand } & \multirow{2}{*}{ Label } & \multirow{2}{*}{$\frac{\text { Type of product }}{\text { (as part of label) }}$} & \multirow{2}{*}{$\begin{array}{l}\text { Packed/ } \\
\text { Produced by }\end{array}$} & \multirow{2}{*}{$\begin{array}{l}\text { Main office } \\
\text { address }\end{array}$} & \multirow{2}{*}{$\frac{\text { Market outlet }}{\text { sold }}$} & \multirow{2}{*}{ Weight } & \multirow{2}{*}{$\begin{array}{l}\text { Price } \\
\text { (PhP) }\end{array}$} & \multirow{2}{*}{$\begin{array}{r}\text { Price/kg } \\
\text { (Php) }\end{array}$} \\
\hline & & & & & & & & \\
\hline Sun Made & Organic* & brown rice & $\begin{array}{l}\text { Mindanao } \\
\text { Agri-network } \\
\text { Corp. } \\
\text { (Mancor) }\end{array}$ & Davao City & SM Makati & $1 \mathrm{~kg}$ & 1.9 & 1.9 \\
\hline $\begin{array}{l}\text { Cordillera } \\
\text { Heritage } \\
\text { Harvest rice }\end{array}$ & Organic* & brown, red, black & Kalinga & Tabuk City Kalinga & & $1 \mathrm{~kg}$ & 2.2 & 2.2 \\
\hline $\begin{array}{l}\text { Kintoman } \\
\text { heirloom rice }\end{array}$ & Organic* & $\begin{array}{l}\text { heirloom rice - } \\
\text { glutinous }\end{array}$ & & Kibungan, Benguet & $\begin{array}{l}\text { Charmp trade } \\
\text { fair in Baguio }\end{array}$ & $1 \mathrm{~kg}$ & 2.1 & 2.1 \\
\hline Kalinga Unoy & Organic* & $\begin{array}{l}\text { organic export } \\
\text { quality - heritage } \\
\text { RED }\end{array}$ & Kalinga & Kalinga & & $1 \mathrm{~kg}$ & 2.6 & 2.6 \\
\hline Kalinga Jekot & Organic* & $\begin{array}{l}\text { organic export } \\
\text { quality - heirloom } \\
\text { (sticky rice) }\end{array}$ & Kalinga & Kalinga & & $1 \mathrm{~kg}$ & 3.3 & 3.3 \\
\hline Jordan Farms & Organic* & red rice & $\begin{array}{l}\text { Sunnywood } \\
\text { Superfoods } \\
\text { corp }\end{array}$ & $\begin{array}{l}479 \text { J. P. Rizal St., } \\
\text { Bgy. Vergara, } \\
\text { Mandaluyong City }\end{array}$ & SM North Edsa & $800 \mathrm{~g}$ & 2.1 & 2.6 \\
\hline Jordan Farms & Organic* & brown & & & SM North Edsa & $800 \mathrm{~g}$ & 1.9 & 2.4 \\
\hline Jordan Farms & Organic* & $\begin{array}{l}\text { tapol de oro, Violet } \\
\text { Rice }\end{array}$ & & & SM North Edsa & $800 \mathrm{~g}$ & 2.3 & 2.9 \\
\hline Jordan Farms & Organic* & black rice & & & SM North Edsa & $2 \mathrm{kgs}$ & 5.0 & 2.5 \\
\hline $\begin{array}{l}\text { F \& C } \\
\text { Forbidden Rice }\end{array}$ & Organic* & black rice & $\begin{array}{l}\text { Upland } \\
\text { Marketing } \\
\text { Foundation, } \\
\text { Inc. }\end{array}$ & Pasig City & SM North Edsa & $500 \mathrm{~g}$ & 1.6 & 3.2 \\
\hline $\begin{array}{l}\text { F \& C Healthy } \\
\text { Rice }\end{array}$ & Organic* & red rice & & & & $500 \mathrm{~g}$ & 1.2 & 2.4 \\
\hline Sun Made & Organic* & brown rice & $\begin{array}{l}\text { Mindanao Agri- } \\
\text { network Corp. } \\
\text { (Mancor) }\end{array}$ & Davao City & $\begin{array}{l}\text { Davao } \\
\text { (Gaisano, } \\
\text { NCCC, } \\
\text { Rustans's) }\end{array}$ & $1 \& 5 \mathrm{kgs}$ & & 1.4 \\
\hline $\begin{array}{l}\text { Dujali Organic } \\
\text { Rice }\end{array}$ & Organic* & black rice & Coop & Davao del Norte & $\begin{array}{l}\text { Davao retail } \\
\text { store }\end{array}$ & $1 \mathrm{~kg}$ & 1.2 & 1.2 \\
\hline $\begin{array}{l}\text { Eighth Wonder } \\
\text { Kalinga Unoy }\end{array}$ & Organic* & Export Red rice & Rice Inc. & $\begin{array}{l}\text { Kalinga, Ifugao, } \\
\text { Mountain Province }\end{array}$ & Outside Phils. & $1 \mathrm{lb}$ & & 12.1 \\
\hline $\begin{array}{l}\text { Eighth Wonder } \\
\text { Tinawon Fancy } \\
\text { Rice }\end{array}$ & Organic* & Export fancy rice & Rice Inc. & $\begin{array}{l}\text { Kalinga, Ifugao, } \\
\text { Mountain Province }\end{array}$ & Outside Phils. & $11 \mathrm{~b}$ & & 12.1 \\
\hline
\end{tabular}


Table 1. cont.

\begin{tabular}{|c|c|c|c|c|c|c|c|c|}
\hline \multirow{2}{*}{$\begin{array}{l}\text { Variety/ } \\
\text { Brand }\end{array}$} & \multirow{2}{*}{ Label } & \multirow{2}{*}{$\frac{\text { Type of product }}{\text { (as part of label) }}$} & \multirow{2}{*}{$\begin{array}{l}\text { Packed/ } \\
\text { Produced by }\end{array}$} & \multirow{2}{*}{$\begin{array}{l}\text { Main office } \\
\text { address }\end{array}$} & \multirow{2}{*}{$\frac{\text { Market outlet }}{\text { sold }}$} & \multirow{2}{*}{ Weight } & \multirow{2}{*}{$\begin{array}{l}\text { Price } \\
\text { (PhP) }\end{array}$} & \multirow{2}{*}{$\begin{array}{c}\text { Price/kg } \\
\text { (Php) }\end{array}$} \\
\hline & & & & & & & & \\
\hline $\begin{array}{l}\text { Eighth Wonder } \\
\text { Ulikan Red }\end{array}$ & Organic* & Export red rice & Rice Inc. & $\begin{array}{l}\text { Kalinga, Ifugao, } \\
\text { Mountain } \\
\text { Province }\end{array}$ & Outside Phils. & $1 \mathrm{lb}$ & & 12.1 \\
\hline Dona Maria & $\begin{array}{l}\text { not labeled as } \\
\text { organic }\end{array}$ & Jasponica brown & $\begin{array}{l}\text { SL Agritech } \\
\text { Corp }\end{array}$ & Laguna & SM North Edsa & $5 \mathrm{kgs}$ & 9.8 & 2.0 \\
\hline $\begin{array}{l}\text { Supermarket } \\
\text { house brand }\end{array}$ & $\begin{array}{l}\text { Not labelled } \\
\text { organic }\end{array}$ & brown rice & & SM & $\begin{array}{l}\text { SM } \\
\text { hypermarket }\end{array}$ & $1 \mathrm{~kg}$ & & 1.3 \\
\hline $\begin{array}{l}\text { Supermarket } \\
\text { house brand }\end{array}$ & $\begin{array}{l}\text { Not labelled } \\
\text { organic }\end{array}$ & violet rice & & SM & $\begin{array}{l}\text { SM } \\
\text { hypermarket }\end{array}$ & $1 \mathrm{~kg}$ & & 1.7 \\
\hline Dona Maria & $\begin{array}{l}\text { not labeled as } \\
\text { organic }\end{array}$ & Miponica brown & $\begin{array}{l}\text { SL Agritech } \\
\text { Corp }\end{array}$ & Laguna & $\begin{array}{l}\text { Robinson's } \\
\text { Davao }\end{array}$ & $5 \mathrm{kgs}$ & 9.8 & 2.0 \\
\hline $\begin{array}{l}\text { Harvester's } \\
\text { Red rice }\end{array}$ & $\begin{array}{l}\text { Not labelled } \\
\text { as organic }\end{array}$ & red rice & $\begin{array}{l}\text { Sunnywood } \\
\text { Superfoods } \\
\text { corp }\end{array}$ & $\begin{array}{l}479 \text { J. P. Rizal } \\
\text { St., } \\
\text { Bgy. Vergara, } \\
\text { Mandaluyong } \\
\text { City }\end{array}$ & $\begin{array}{l}\text { Robinson's } \\
\text { Davao }\end{array}$ & $5 \mathrm{kgs}$ & 7.9 & 1.6 \\
\hline $\begin{array}{l}\text { Dinorado PG } \\
\text { Rice }\end{array}$ & $\begin{array}{l}\text { Not labelled } \\
\text { as organic }\end{array}$ & Dinorado & & & $\begin{array}{l}\text { Robinson's } \\
\text { Davao }\end{array}$ & $25 \mathrm{kgs}$ & 26.9 & 1.1 \\
\hline
\end{tabular}

*labelled as organic but without certification; Source: Market Monitoring November 2014

Table 2. Price of traditional rice by type of label

\begin{tabular}{lll}
\hline Type of label & Average Price (USD) & \% Difference to Certified organic \\
\hline Certified Organic & 2.9 & \\
Organic* & 2.4 & 20 \\
Not labelled as organic & 1.6 & 51 \\
\hline
\end{tabular}

* Labelled as organic but without certification

On the other hand, average price of rice brands that are labelled organic but do not have organic certification is USD 2.4 per $\mathrm{kg}$. and the price ranges from USD 2.3 - USD 3.3/ kg. The average price for certified organic rice is $20 \%$ higher than those labeled as organic but without certification and about 51\% higher than traditional rice (red, black or brown) not labeled as organic.

A number of these products labelled as organic but without certification are packed in different weights. For example, F \& C Forbidden rice (black rice) and F \& C Health rice brands are packed at 500g. Jordan Farms is another brand 
having red, black, brown, Violet, and Black varieties of rice which were packed at 800g and available in SM North Edsa and other SM outlets. Other heirloom organic rice packed in $1 \mathrm{~kg}$ were also showcased during trade fair in Baguio City in November 2014 which included Cordillera Harvest Rice, Kintoman heirloom, Kalinga Unoy, and Kalinga Jekot.

Eighth Wonder brands showcasing heirloom rice from Ifugao and Kalinga are exported and available online. Price ranges from USD5.75 - 6.50/lb or USD 12.1/kg. excluding shipping cost (http://www.heirloomrice.com/store/allprods.php).

Other red and brown type of rice that are not labelled as organic have lower price ranging from USD 1.1- USD 1.9/kg. with an average of USD $1.6 / \mathrm{kg}$.

\subsection{Location}

Considering the market outlet of the traditional rice, average price in Luzon is higher by $85 \%$ compared to Mindanao (Table 3). If we consider the label for each location, average price of certified organic rice sold in Luzon is higher by $33 \%$ and $107 \%$ higher than those that are not certified and not labelled as organic respectively (Table 4). However, in the case of traditional rice sold in Mindanao, price of certified organic rice is lower by $9 \%$ compared to non-certified, and much lower by $32 \%$ compared to those that are not labelled as organic. This is mainly due to transportation cost and the source of raw material. For example, Bios dynamis with raw materials (produced) in Mindanao is sold at USD 1.2 per $\mathrm{kg}$ in Mindanao and USD 3.9 per $\mathrm{kg}$ in Manila. Also, another product labelled as organic but without certification and produced from Davao del Norte has the same price as Bios Dynamis sold in Davao City at USD 1.2 per $\mathrm{kg}$. Another brand (Sun Made) which is based in Mindanao sold at USD 1.4 per kg which is higher than Bios Dynamis. However, this is still relatively cheap compared to those sold in Manila. This also indicates high marketing or retail costs in Manila.

Table 3. Average price of traditional varieties by location

\begin{tabular}{lll}
\hline Location & Ave. Price(USD) & \% difference \\
\hline Luzon & 2.6 & \\
Mindanao & 1.4 & 85 \\
\hline
\end{tabular}

Table 4. Average price of traditional varieties by type of label, and by location

\begin{tabular}{|c|c|c|c|c|}
\hline \multirow[b]{2}{*}{ Label } & \multicolumn{2}{|c|}{ Luzon } & \multicolumn{2}{|c|}{ Mindanao } \\
\hline & $\begin{array}{c}\text { Average Price } \\
\text { (USD) }\end{array}$ & $\begin{array}{c}\text { Price Difference to } \\
\text { certified organic }\end{array}$ & $\begin{array}{c}\text { Average Price } \\
\text { (USD) }\end{array}$ & $\begin{array}{c}\text { Price Difference to } \\
\text { certified organic }\end{array}$ \\
\hline Certified organic & 3.4 & & 55 & \\
\hline Organic* & 2.6 & $33 \%$ & 1.3 & $-9 \%$ \\
\hline Not labelled as organic & 1.7 & $107 \%$ & 1.8 & $-32 \%$ \\
\hline
\end{tabular}

* Labelled as organic but without certification

\subsection{Type (color and glutinous)}

On the average, red rice is priced higher by $7 \%$ and $17 \%$ than black and brown rice respectively (Table 5). Violet/ glutinous rice is priced differently since it is not used as staple food but as ingredient to special delicacies. On the average, Luzon price is $105 \%$ higher than the price in Mindanao.

If we consider the label, certified organic red rice sold in Luzon has an average price of USD 3.4/kg with price ranging from USD 2.9 - USD 3.9 per $\mathrm{kg}$. This is 44\% higher than those without certification (Table 6). Similar to red rice, price of brown rice, black rice, and violet/purple/glutinous rice sold in Luzon are also higher by 63\%, 49\%, and 60\% respectively compared to those without certification. But this is not the case in Mindanao wherein certified organic rice is lower by $24 \%$ and $16 \%$ for red rice and brown rice, respectively. 
Table 5. Price of traditional rice by type of product and by location

\begin{tabular}{lccccc}
\hline \multirow{2}{*}{ Product } & $\begin{array}{c}\text { Ave. Price } \\
\text { (USD) }\end{array}$ & $\begin{array}{c}\text { \% difference } \\
\text { to Red rice }\end{array}$ & \multicolumn{2}{c}{ Ave. Price (USD) } & Difference between Luzon \& \\
& 2.5 & & 2.9 & 1.4 & $110 \%$ \\
\hline Red & 2.4 & $7 \%$ & 2.9 & 1.2 & $146 \%$ \\
Black & 2.2 & $17 \%$ & 2.4 & 1.5 & $58 \%$ \\
Brown & 2.5 & $2 \%$ & 2.5 & & \\
Violet/Glutinous & $105 \%$ & & & & \\
Average & & & & \\
\hline
\end{tabular}

Table 6. Average price of traditional varieties by type of product and location

\begin{tabular}{|c|c|c|c|c|}
\hline \multirow{2}{*}{$\begin{array}{l}\text { Label } \\
\text { Red Rice }\end{array}$} & \multicolumn{2}{|c|}{ Luzon } & \multicolumn{2}{|c|}{ Mindanao } \\
\hline & Average Price & $\begin{array}{c}\text { Price Difference to } \\
\text { organic }(\%)\end{array}$ & Average Price & $\begin{array}{c}\text { Price Difference to } \\
\text { organic }(\%)\end{array}$ \\
\hline Certified organic & 3.4 & & 1.2 & \\
\hline organic* & 2.4 & 44 & 1.6 & -24 \\
\hline \multicolumn{5}{|l|}{ Brown Rice } \\
\hline Certified organic & 3.9 & & 1.2 & \\
\hline organic* & 2.4 & 63 & 1.4 & -16 \\
\hline Not labelled as organic & 1.6 & 47 & 2.0 & -28 \\
\hline \multicolumn{5}{|l|}{ Black rice } \\
\hline Certified organic & 3.9 & & 1.2 & \\
\hline organic* & 2.6 & 49 & 1.2 & - \\
\hline \multicolumn{5}{|l|}{ Violet/purple/Glutinous } \\
\hline organic* & 2.7 & & & \\
\hline Not labelled as organic & 1.7 & 60 & & \\
\hline
\end{tabular}

Clearly, labelling (eg certification), location and variety or type (eg color) affect price of traditional varieties of rice. The above results also show that ecolabeled products such as organic (with or without certification) fetch a higher price. In what follows, factors that affect the willingness of consumers to pay based on the survey results are discussed.

\section{Willingness to pay for ecolabeled products}

In terms of demographics, about $73 \%$ of the respondents are women and $58 \%$ are below 44 years old. Majority of the respondents are highly educated. More than half (53\%) went to college, $41 \%$ with post-graduate studies, $6 \%$ went to high school and less than a percent had elementary education. More than a third of the respondents have monthly income from USD 326 to USD 652, 22\% have income below USD 326, 18\% between USD 652 to USD 1,087 and about $14 \%$ have income higher than USD 1,087.

In terms of psychographics or lifestyle, $80 \%$ of the respondents consider themselves health conscious. However, only $15 \%$ of the sample have been using products that are labelled organic. In terms of the frequency of using organic products, about 39\% consume regularly or at least once a week and $61 \%$ said they rarely consume organic products. There is a higher percentage of respondents who said they consume either regularly (at least once a week) or rarely than those who consume products that are labelled organic. This can be attributed to possible reasons. One is the notion that the product referred to when they were asked about the frequency of consumption is not necessarily certified or labelled as organic. The other possibility is that those there were some respondents who consume regularly or rarely do not consider themselves as someone who consume products that are labelled organic as this means regularly consuming more than once a week. When asked about the reasons for not consuming or regularly consuming organic products, about $35 \%$ said that they are not available in the market, $31 \%$ found price expensive and the same percentage said they are unsure if they are really organic. 


\subsection{Willingness to pay}

About $95 \%$ of the respondents are willing to pay for price premium for certified organic rice. This is only $1 \%$ higher compared to the percentage of respondents who are willing to pay for organic rice without certification. This is perhaps one of the reasons why of the 16 brands of traditional rice varieties (red, brown and black) surveyed, only 3 or $18 \%$ have organic certification either from OCCP (Organic Certification Center of the Philippines) or NICERT (Negros Island Certification). However, a different story emerges if one examines the specific price premium that consumers are willing to pay (see below).

The high percentage of respondents willing to pay for price premium can be due to their high level of income and education. About $94 \%$ of them have gone to college and $78 \%$ having monthly income of more than USD 326. Further insights can be gleaned on the factors that affect level of price premium through the models estimated (see discussion below). In addition, the high percentage of respondents who are willing to pay show the size of the market for these products if they are made available, affordable and claims verified.

\subsection{Price premium}

In terms of the price premium respondents are willing pay for all rice products, about $26 \%$ are willing to pay above $21 \%$ price premium where $16 \%$ are willing to pay price premium between $21 \%$ to $40 \%$ and only $10 \%$ are willing to above $40 \%$ premium. Approximately $39 \%$ are willing to pay between $10 \%$ to $20 \%$ price premium and $35 \%$ are willing to pay below $10 \%$ price premium. This trend follows the law of demand such that the willingness to pay (WTP) decreases as the price premium increases. This is illustrated in Figure 4 which shows the average \% of respondents of all products ( $\mathrm{y}$ axis) against the price premium $(\mathrm{PP})$ categories ( $\mathrm{x}$ axis).

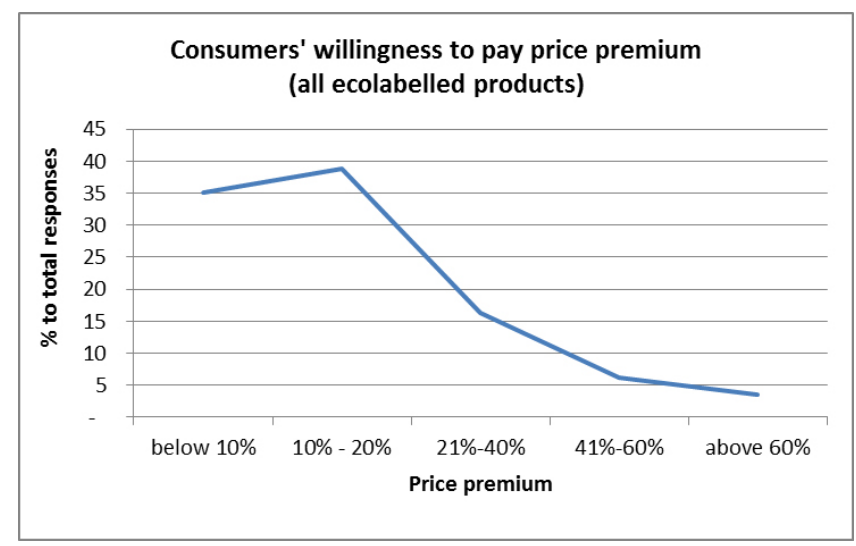

Figure 4. Consumers' willingness to pay price premium for all ecolabelled products

Figure 4, however, shows a "kinked demand curve" since the percentage of respondents WTP the lowest range of price premium (below 10\%) is lower than the next higher range of price premium (10\% to $20 \%$ ) but not compared to the other range of price premium. This kink implies that majority of the respondents are willing to pay a minimum or threshold price premium between $10 \%$ to $20 \%$ to compensate for environmental claims or attributes.

It is interesting to note that the kinked curve applies to all products except for rice without certification which follows a normal (without a kink) downward sloping demand curve (Figure 4). This indicates that certification differentiates the product such that it fetches a higher threshold level.

There are also some notable differences in the price premiums that consumers are willing to pay when it comes to specific products. For example, while there is only $1 \%$ difference in the percentage of respondents who are willing to pay for price premium between certified organic rice and organic rice without certification, there is a large difference in terms of the price premium consumers are willing to pay between these products. For rice products without organic certification, about $56 \%$ of the respondents are willing to pay a price premium of less than $10 \%$ compared to only $26 \%$ for rice with organic certification. Also, about $35 \%$ of the respondents are willing to pay price premium higher than $20 \%$ for rice with certification compared to only $14 \%$ for rice without certification. Thus, more consumers are willing to pay higher prices for certified organic products. This is consistent with the existing prices surveyed in market outlets of 17 brands where average price of 3 brands that have organic certification was $25 \%$ higher compared to brands without certification. 


\subsection{Factors affecting level of price premium}

Results of the survey as well as the model estimated show that there are several demographic and psychographic factors that may affect the level of price premium that consumers are willing to pay. Demographic factors include gender, age, education and income and psychographic factors include level of health consciousness and whether the respondent is a consumer of organic products.

\subsubsection{Demographic factors}

In terms of gender, women are willing to pay higher price premium that men. For all ecolabelled products, an average of about $86 \%$ of men are willing to pay price premium below $20 \%$ compared to only $70 \%$ for women. On the other hand, only $14 \%$ of men are willing to pay more than $20 \%$ price premium compared to $30 \%$ for women. Particularly for certified organic rice, $41 \%$ of women are willing to pay more than $20 \%$ premium compared to only $15 \%$ for men. Also for products certified to preserve heritage sites, only $13 \%$ of men are willing to pay for price premium above $20 \%$ compared to $27 \%$ for women but the opposite is true for price premium below $20 \%$.

For age, there is not much a pattern in terms of the willingness to pay. Respondents who belong to three age categories below 44 years old do not have much difference in terms of their willingness to pay across price premium categories. On the average, about $77 \%$ of them are willing to pay price premium below $20 \%$ and $23 \%$ of them are willing to pay price premium above $20 \%$. This is different compared to respondents belonging to age group $45-54$ where $63 \%$ are willing to pay price premium below $20 \%$ and $37 \%$ are willing pay above $20 \%$ price premium. About a quarter in this age group are willing to pay premium between $21 \%-40 \%$.

In terms of educational attainment, there is a big difference in the willingness to pay between respondents who went to high school compared to those who went to college or did some postgraduate studies. On the average considering all products, most of those who went to high school (about 90\%) are willing to pay price premium below 20\% compared to $73 \%$ for those who went to college or post-graduate studies. The difference between those who went to college and to those who went to postgraduate studies is not as big compared to those who went to high school. However, there is a relatively a higher percentage of respondents who went to post graduate studies who are willing to pay for higher premium compared to those who went to college. About $45 \%$ of those who went to post-graduate studies are willing to pay price premium between $10 \%$ to $20 \%$ compared to $34 \%$ for those who went to college. On the other hand, only $29 \%$ of those who went to post-graduate studies are willing to pay price premium below $10 \%$ compared to $39 \%$ for those who went to college. The pattern is similar at the product level.

Income appears to be not affecting the level of price premium that respondents are willing to pay. The percentage of respondents willing to pay price premium lower than $20 \%$ does not vary across income brackets which ranges from $71 \%$ to $80 \%$. In fact, when these income brackets are the aggregated from five into two brackets (those below USD 652 per month and those above USD 652 per month), the difference between the percentage of respondents willing to pay below $20 \%$ premium between these two income categories is almost nil (only 1\%). However, there is some difference when we disaggregate the price premium below 20\%. A larger percentage of respondents are willing to pay price premium below $10 \%$ for those who have lower income but the opposite is true for higher price premium between $10 \%$ to $20 \%$. In this case, more of those who have higher income are willing to pay higher premium albeit the difference is only $6 \%$.

\subsubsection{Psychographic factors}

The effect of a respondent who is already consuming organic products on the level of price premium he or she is willing to pay is compared to the one who is not consuming organic products. Considering all ecolabelled products covered, the data show that there is not much difference between those who are already consuming organic products and those who are not. About $41 \%$ of those who are already consuming organic products and about $43 \%$ of those who are not, are willing to pay price premium below $20 \%$. The small difference between the two types of respondents generally applies at a product level except for certified organic rice where the difference is quite significant. About $83 \%$ of those who are not consuming organic products are willing to pay less than $20 \%$ compared to $63 \%$ for those who are consuming products. Thus, only $17 \%$ of those who are not consuming organic rice are willing to pay price premium more than $20 \%$ compared to $37 \%$ for those who are already consuming. As expected, those who are already consuming organic rice are willing to pay higher prices compared to those who are not consuming organic products. In fact, almost a quarter of those who are already consuming organic rice are willing to pay price premium between $21 \%$ to $40 \%$.

The effect of the level of health consciousness on the price premium is similar to the one whether the respondent is 
a consumer of organic products or not. Generally, there is no significant difference between the price premium that a consumer who considers himself health conscious is willing to pay compared to a consumer who does not consider himself health conscious. Considering all products, about $78 \%$ of the respondents who are not health conscious are willing to pay less than $20 \%$ price premium compared to $73 \%$ for those who are health conscious. Alternatively, there are $27 \%$ of health conscious respondents are willing to pay more than $20 \%$ price premium compared to only $22 \%$ for those who are not health conscious. However, the difference becomes bigger in the case of certified organic rice. For example, $41 \%$ and $23 \%$ of health conscious respondents are willing to pay price between $10 \%$ to $20 \%$ and $21 \%$ to $40 \%$ respectively. For those who are not health conscious, only $12 \%$ are willing to pay price premium between $21 \%$ to $40 \%$. Also, about $39 \%$ of those who are not health conscious are willing to pay less than $10 \%$ price premium compared to only $23 \%$ for those who are health conscious.

An econometric model using integral regression was estimated to simultaneously examine the effect of both demographic and psychographic factors on the level of price premium that consumers are willing to pay.

Generally, the results are consistent with the findings in the previous section where each demographic or psychographic factor is related to the level of price premium that consumers are willing to pay. The advantage is that it provides whether the relationship between these factors and the price premium is statistically significant. The model also provides a quantification of the magnitude and the direction of this relationship.

For certified organic rice, the older the respondents the higher their willingness to pay price premium. A respondent is willing to pay $0.2 \%$ more for certified organic rice than a respondent that is one year younger. Respondents that consider themselves health conscious are willing to pay $4.3 \%$ more for certified organic rice. Respondents who are already consuming organic-labeled products are willing to pay $4 \%$ more for certified organic rice compared to those who have not consume organic-labeled products. The five income levels were represented in the model by four dummy variables, each representing the first four income level. The $5^{\text {th }}$ income level is represented in the model when all the dummy variables are all zeros. Thus, the coefficients of the four dummy variables can be interpreted as the difference in price premium respondents from the first four income levels are willing to pay from the respondents from the last income level. For example, a respondent from the fourth income level is willing to pay $14 \%$ more than the respondents from the fifth income level. Positive coefficients of the four dummy variables indicate that the four lower income level is willing to pay more for certified organic rice than the respondents from the fifth (highest) income level. Also, except for the fourth income level, the value of the coefficients declines as we move up in the income levels $(0.16,0.13$ and 0.11 for income levels 1, 2 and 3). Therefore, we can infer from the sample that the higher the income the respondents have the lower the price premium they are willing to pay for certified organic rice (Table 7).

Table 7. Certified organic rice, interval regression results

\begin{tabular}{|llllll|}
\hline $\begin{array}{l}\text { Missing or incomplete observations dropped: } 2 \\
\text { Lower limit: eL, Upper limit: eU } \\
\text { Standard errors based on Hessian }\end{array}$ & & & & \\
& Coefficient & Std. error & $\mathbf{z}$ & p-value & \\
Const & -0.149234 & 0.0922376 & -1.618 & 0.1057 & \\
Age & 0.00271338 & 0.00101394 & 2.676 & 0.0074 & $* * *$ \\
Healthconscious & 0.0430959 & 0.0234174 & 1.840 & 0.0657 & $*$ \\
Consumeproducts1 & 0.0406419 & 0.0242781 & 1.674 & 0.0941 & $*$ \\
Gender & -0.0179708 & 0.0278757 & -0.6447 & 0.5191 & \\
DIncomeLevel_1 & 0.164823 & 0.0651434 & 2.530 & 0.0114 & $* *$ \\
DIncomeLevel_2 & 0.134602 & 0.0597059 & 2.254 & 0.0242 & $* *$ \\
DIncomeLevel_3 & 0.112156 & 0.0598957 & 1.873 & 0.0611 & $*$ \\
DIncomeLevel_4 & 0.147769 & 0.0636814 & 2.320 & 0.0203 & $* *$ \\
Chi-square (8) & 17.49189 & P value & & 0.025376 & \\
Log-likelihood & -54.37245 & Akaike criterion & & 128.7449 & \\
\hline
\end{tabular}


Table 7. cont.

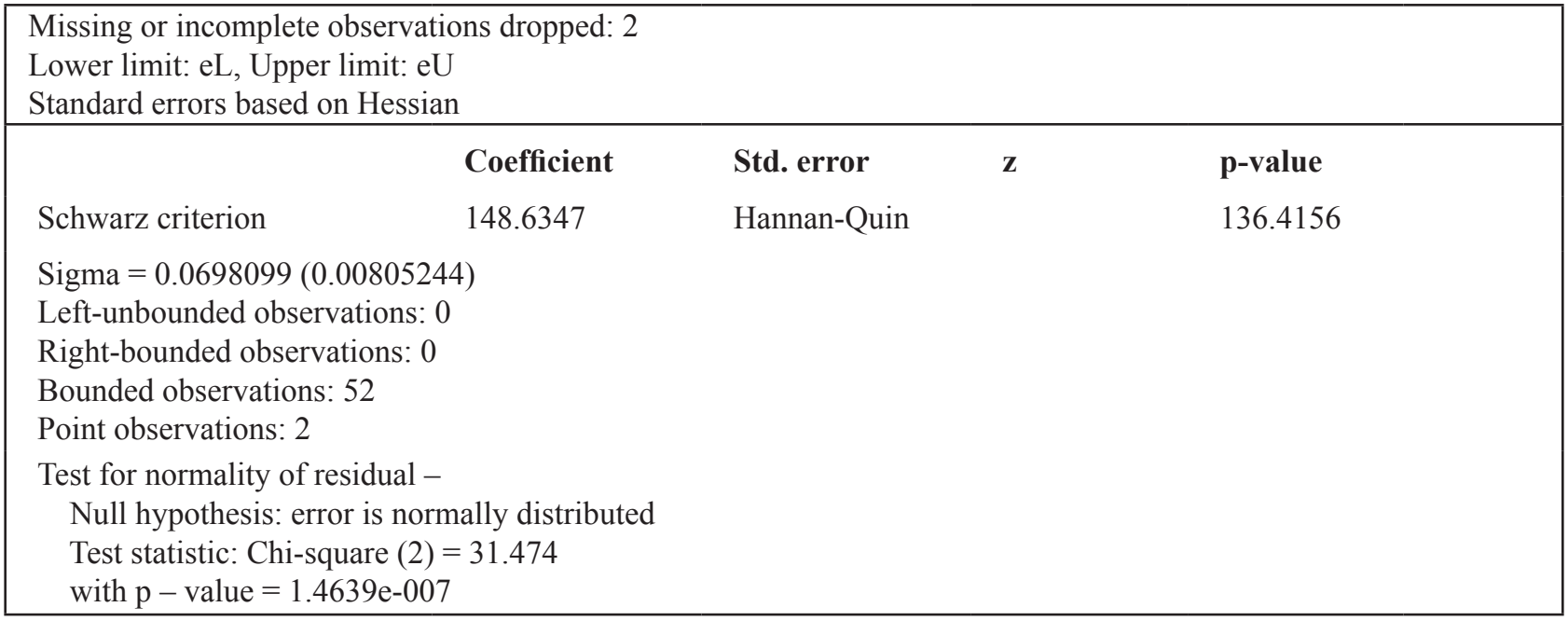

For rice products certified to preserve banawe rice terraces as a cultural heritage site, the older the respondents the higher their willingness to pay (price premium). A respondent is willing to pay $0.3 \%$ more for rice products certified to preserve banawe rice terraces as a cultural heritage site than a respondent that is one year younger.Unlike in the "certified organic rice" case, this time all the coefficients of the income levels, except for the third income level, have, more or less, the same value. However, results still show that the four income levels are willing to pay more compared to the fifth income level. This may be due to the discrepancy in sample size from the fifth income level (Table 8).

Summary of the effects of psychographic and demographic factors is presented in Table 9.

Table 8. Rice products certified to preserve banawe rice terraces as a cultural heritage site, interval regression results

\begin{tabular}{|c|c|c|c|c|c|}
\hline \multicolumn{6}{|c|}{$\begin{array}{l}\text { Missing or incomplete observations dropped: } 2 \\
\text { Lower limit: fL, Upper limit: fU } \\
\text { Standard errors based on Hessian }\end{array}$} \\
\hline & coefficient & Std. error & $\mathbf{z}$ & p-value & \\
\hline Const & -0.138025 & 0.0714361 & -1.932 & 0.0533 & $*$ \\
\hline Age & 0.00342714 & 0.000788688 & 4.345 & $1.39 \mathrm{e}-05$ & $* * *$ \\
\hline Healthconscious & -0.0117332 & 0.0188956 & -0.6209 & 0.5346 & \\
\hline Consumeproducts $1^{\sim}$ & 0.0219005 & 0.0195023 & 1.123 & 0.2614 & \\
\hline Gender & -0.0245018 & 0.0221820 & -1.105 & 0.2693 & \\
\hline DIncomeLevel_1 & 0.112761 & 0.0492654 & 2.289 & 0.0221 & $* *$ \\
\hline DIncomeLevel_2 & 0.121456 & 0.0448713 & 2.707 & 0.0068 & $* * *$ \\
\hline DIncomeLevel_3 & 0.0779774 & 0.0450695 & 1.730 & 0.0836 & $*$ \\
\hline DIncomeLevel_4 & 0.110548 & 0.0482271 & 2.292 & 0.0219 & $* *$ \\
\hline Chi-square (8) & 24.99446 & $P$ value & & 0.001558 & \\
\hline Log-likelihood & -41.22813 & Akaike criterion & & 102.4563 & \\
\hline Schwarz criterion & 122.3461 & Hannan-Quin & & 110.1270 & \\
\hline $\begin{array}{l}\text { Sigma }=0.0535422 \\
\text { Left-unbounded obse } \\
\text { Right-bounded obser } \\
\text { Bounded observation } \\
\text { Point observations: } 3\end{array}$ & & & & & \\
\hline $\begin{array}{l}\text { Test for normality of } \\
\text { Null hypothesis: er } \\
\text { Test statistic: Chi-s } \\
\text { with } p \text { - value }=9 \text {. }\end{array}$ & $\begin{array}{l}\text { ally distributed } \\
46.1715\end{array}$ & & & & \\
\hline
\end{tabular}


Table 9. Effects of demographic and psychographic factors on price premium

\begin{tabular}{|c|c|c|}
\hline Ecolabelled Products & $\begin{array}{l}\text { Statistically significant } \\
\text { variables }\end{array}$ & Quantitative effect of significant variables \\
\hline Certified Organic rice & $\begin{array}{l}\text { Gender } \\
\text { Consuming organic products }\end{array}$ & $\begin{array}{l}\text { - Women are willing to } 8.5 \% \text { higher compared to men } \\
\text { - Those who are already consuming organic products are } \\
\text { WTP } 6 \% \text { more compared to those who are not } \\
\text { consuming organic products }\end{array}$ \\
\hline $\begin{array}{l}\text { Rice products labelled/ } \\
\text { sold as organic but } \\
\text { without official organic } \\
\text { certification }\end{array}$ & $\begin{array}{l}\text { Gender } \\
\text { Age } \\
\text { Income }\end{array}$ & $\begin{array}{l}\text { - Women are WTP } 5 \% \text { higher compared to men } \\
\text { - PP increases by } .17 \% \text { per additional year (age) } \\
\text { - Consumers with income above USD } 652 \text { per month are } \\
\text { WTP } 4 \% \text { lower compared to those with income below } \\
\text { USD } 652 \text { per month }\end{array}$ \\
\hline $\begin{array}{l}\text { Rice products certified } \\
\text { to preserve Ifugao rice } \\
\text { terraces as a cultural } \\
\text { heritage site }\end{array}$ & $\begin{array}{l}\text { Gender } \\
\text { Consuming organic products }\end{array}$ & $\begin{array}{l}\text { - Women are willing to pay } 6 \% \text { higher compared to men } \\
\text { - Those who are already consuming organic products are } \\
\text { WTP 5\% more compared to those who are not } \\
\text { consuming organic products }\end{array}$ \\
\hline
\end{tabular}

\section{Concluding comments}

Most consumers are willing to pay for ecolabelled products but the willingness varies depending on the level of price premium. These include products certified to conserve agro-biodiversity, indigenous varieties including rice, cultural heritage (eg hadwoven products from abaca), certified organic rice, etc.

The willingness to pay decreases as price premium increases which follows the normal demand curve. However for most ecolabelled products except rice without organic certification (the only one without certification), there is kinked demand which implies that there is a minimum price premium that most consumers are willing to pay.

Certification fetches higher price. All the nine ecolabelled products considered are certified except one on rice products sold as organic but without certification. The latter follows the normal downward sloping demand curve with majority of the respondents willing to pay the lowest possible price (below 10\%). This is consistent with the actual prices monitored from various market outlets.

Majority of the respondents are willing to pay price premium for ecolabelled products that range from $10 \%$ to $20 \%$. About $75 \%$ of the respondents are willing to pay price premium for ecolabelled products below $20 \%$ and about a quarter are willing to pay above $20 \%$. About $15 \%$ of the respondents are already consuming organic products. One of the possible reasons is that currently, ecolabelled products such as the traditional rice varieties (red, brown and black) labelled as organic with or without certification are currently price more than $20 \%$, in fact $104 \%$ more compared to those traditional rice not labelled organic. Thus, a lower price may expand the market. In fact more than $30 \%$ of the respondents cited high price of organic product as one of the reasons why they don't purchase it.

Modelling results show that gender, age, income and being an organic consumption consumer significant affect the level of price premium.

\section{Funding Statement}

This work was supported by the Food and Agriculture Organization (FAO)

\section{References}

[1] Akiefnawati, R., Ayat, A. Budisetiawan, I., Mulyoutami, E. Noordwijdk, Mv., Villamor, GB., Zulfikar, F. (2011). Stewardship Agreement to Reduce Emissions from Deforestation and Degradation (REDD): case study from Lubuk Beringin's Hutan Desa, Jambi Province, Sumatra, Indonesia, World Agroforestry Centre

[2] Amstel, M., Brauw, C., Driessen, P. (2007). The reliability of product-specific eco-labels as an agrobiodiversity management instrument, Biodiveristy and Conservation, Vol. 16, Issue 14, pp. 4109-4129 
[3] Amstel, M., Driessen P., Glasbergen, P. (2008). Eco-labeling and Information Assymmetry: a comparison of five eco-labels in the Netherlands, Journal of Cleaner Production, Vol. 16, Issue 3, pp. 263-267

[4] Concepcion, S., Digal, L., Guarin, R., Hualda, AL. (2008). Keys to Inclusion of Small-Scale Organic rice Producers in Supermarkets: the Case of Upland Marketing Foundation, Inc., in the book Changing Agrifood Markets in Southeast Asia: Impacts on Small-Scale Producers, pp. 208 - 292

[5] Guerra, J. (2004), Geographical Indications and Biodiversity: Bridges Joining Distant Territories, Bridges, www. iprsonline.org

[6] Ottman, J., Stafford, E., Hartman, C. (2010). Avoiding Green Marketing Myopia: Ways to Improve Consumer Appeal for Environmentally Preferable Products, Environment: Science and Policy for Sustainable Development, Vol. 48, Issue 5, pp. 22-36

[7] State of the Sector Report on Philippine Organic Products 2006 (2007). Pearl2 Project, www.philexport.ph

[8] The Economy and Environment Program for Southeast Asia (EEPSEA) Policy Brief No. 2013-PB8, Eco-labelling Offers a Sustainable Future for Indonesian Coffee, www.eepsea.org

[9] Treves, A., Jones, SM. (2009). Strategic Trade-offs for Wildlife-friendly Ecolabels, Frontiers in Ecology and the Environment, DOI:10.1890/080173

[10] Aoki, K., Akai, K., and Ujie, K. (2016). A choice experiment to compare preferences for rice in Thailand and Japan: The impact of origin, sustainability, and taste, Food Quality and Preferences, Vol. 56, Part B, pp 274-284

[11] Flamohe R., Nakelse, T., Diagne, A., and Seck, P. (2015). Assessing the effect of consumer purchasing criteria for types of rice in Togo: a choice modelling approach. Agribusiness, Vol 31 (3)

[12] Kajale D., and Baker, T. (2015). Willingness to pay for golden rice in India: A contingent valuation method analysis. Journal of Food Products Marketing, Vol 21(4)

[13] Proctor, F., and Digal, L. (2008). Opportunities for small-scale producers' inclusion in dynamic markets in developing countries and transition economies, Regoverning Markets

[14] Rex, E., and Baumann, H. (2006). Beyond ecolabels: what green marketing can learn from conventional marketing. Journal of Cleaner Production, Vol. 15, pp 567-576

[15] Sirieix, L., Kledal, P., and Sulitang, T. (2011). Organic food consumer's trade-offs between local or imported, conventional or organic products: a qualitative study in Shanghai. International Journal of Consumer Studies

[16] Sriwaranun, Y., Gan, C., Lee, M., and Cohen, D. (2015). Consumer's willingness to pay for organic products in Thailand, International Journal of Social Economics, Vol 42(5) pp 480-510

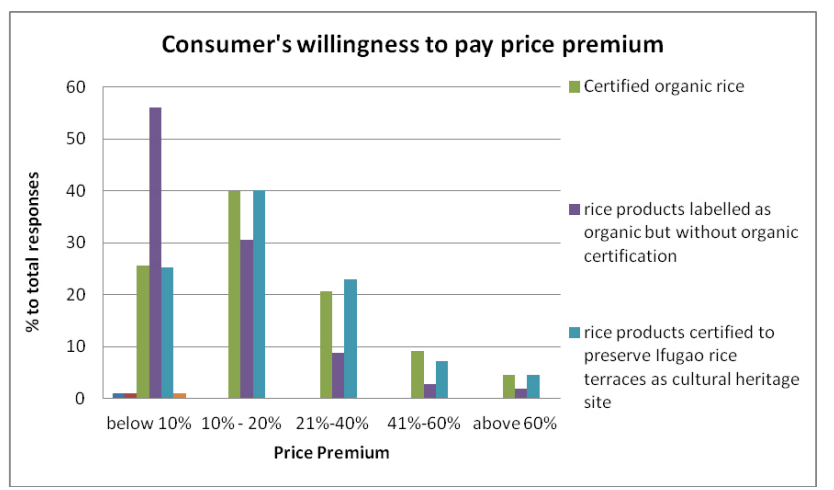

Figure 5. Consumer's willingness to pay price premium by product

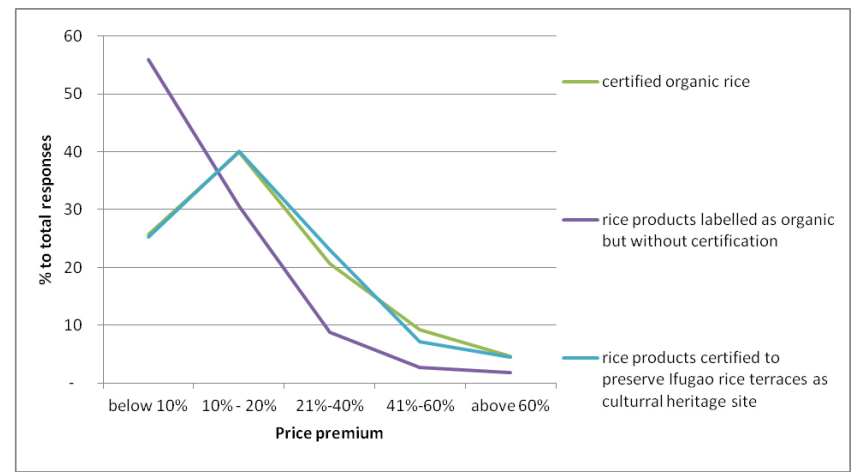

Figure 6. Consumers' willingness to pay price premium by product 